\title{
Covid-19 in familial cluster: ultrashort incubation period could be an early indication of Brazilian Variant of SARS-Cov-2 virus?
}

\author{
Grupo familiar com Covid-19: um período de incubação ultracurto poderia ser indicação \\ precoce da Variante Brasileira do vírus SARS-CoV-2?
}
Grupo familiar con Covid-19: ¿podría el período de incubación ultracorto ser una indicación temprana de la Variante Brasileña del virus SARS-CoV-2?

Gilvano Amorim Oliveira ${ }^{1 *}$, Giovana Martins Lopes Oliveira'.

\begin{abstract}
Objective: To describe the occurrence of COVID-19 with an ultra-short incubation period in a familial cluster. Experience report: Description of a series of eighteen cases of COVID-19 from the same familial cluster, with possible contamination at a social dinner. The time elapsed between the family reunion and the onset of each guest's symptoms was described. The cases that have been tested and their results are presented. Experience report: Nineteen people from a family group were followed for twelve days. The average incubation period was 37.16 hours. The incubation period was 24 hours in $11.11 \%$ of the cases, 36 hours in $66.67 \%$ and 48 hours in $22.22 \%$ of the individuals in the cluster. In just over five percent of patients, the estimated incubation period was 96 hours. The most frequent initial symptom was cough (38.8\%). Final considerations: An ultrashort incubation period for SARS-CoV-2 can be an important alert for a new COVID-19 standard. However, our study is limited by the scarce number of individuals and the lack of tests before the meeting.
\end{abstract}

Keywords: SARS-CoV-2, Covid-19, Short incubation period, Variant of SARS-CoV-2.

\section{RESUMO}

Objetivo: Descrever a ocorrência de COVID-19 com período de incubação ultracurto em um grupo familiar. Relato da experiência: Descrição de uma série de dezoito casos de COVID-19 de um mesmo grupo familiar, com possível contaminação em jantar social. Foi descrito o tempo decorrido entre a reunião familiar e o aparecimento dos primeiros sintomas para cada hóspede. Os casos que foram testados e seus resultados são apresentados. Relato de experiência: Dezenove pessoas de um grupo familiar foram acompanhadas por doze dias. O período médio de incubação foi de 37,16 horas. O período de incubação foi de 24 horas em $11,11 \%$ dos casos, de 36 horas em $66,67 \%$ e de 48 horas em $22,22 \%$ dos indivíduos do cluster. Em pouco mais de cinco por cento dos pacientes, o período de incubação estimado foi de 96 horas. O sintoma inicial mais frequente foi tosse $(38,8 \%)$. Considerações finais: Um período de incubação ultracurto para SARSCoV-2 pode ser um alerta importante para um possível novo padrão de COVID-19. Porém, nosso estudo é limitado pelo número escasso de indivíduos e pela falta de exames antes do encontro.

Palavras-chave: SARS-CoV-2, Covid-19, Curto período de incubação, Variante de SARS-CoV-2.

\section{RESUMEN}

Objetivo: Describir la ocurrencia de COVID-19 con un período de incubación ultra corto en un grupo familiar. Informe de experiencia: Descripción de una serie de dieciocho casos de COVID-19 del mismo grupo familiar,

\footnotetext{
${ }^{1}$ Pontifical Catholic University of Campinas (PUCCAMP), Campinas - SP.

*E-mail: gilvano.oliveira@puc-campinas.edu.br
} 
con posible contaminación en una cena social. Se describió el tiempo transcurrido entre el encuentro familiar y la aparición de los primeros síntomas de cada huésped. Se presentan los casos que se han probado y sus resultados. Informe de experiencia: Diecinueve personas de un grupo familiar fueron seguidas durante doce días. El período medio de incubación fue de 37,16 horas. El período de incubación fue de 24 horas en el $11,11 \%$ de los casos, de 36 horas en el 66,67\% y de 48 horas en el 22,22\% de los individuos del cluster. En poco más del 5 por ciento de los pacientes, el período de incubación estimado fue de 96 horas. El síntoma inicial más frecuente fue la tos $(38,8 \%)$. Consideraciones finales: Un período de incubación ultracorto para el SARS-CoV-2 puede ser una gran señal de alerta para un posible nuevo estándar COVID-19. Sin embargo, nuestro estudio está limitado por el reducido número de personas y la falta de exámenes previos.

Palabras clave: SARS-CoV-2, Covid-19, Período de incubación corto, Variante de SARS-CoV-2.

\section{INTRODUCTION}

Coronavirus disease 2019 (COVID-19) has emerged as a deadly disease worldwide since 2019, with symptoms such as fever, cough, shortness of breath, headache, diarrhea, anosmia, apathy, asthenia, myalgia, nausea and vomiting (LI H, et al., 2019; LAI CC, et al., 2020; VILLAPOL S, 2020).

The clinical events of COVID-19 are related to inflammatory storm, with risk of thromboembolic complications (FARA A, et al., 2020; RIBES A, 2020). The virus that causes COVID-19, severe acute respiratory syndrome coronavirus 2 (SARS-CoV-2), spreads easily, causing several clinical syndromes, with economic impacts and effects devastating social.

Throughout 2020, the spread of coronavirus took on dimensions of one of greatest pandemics in human history, with proportions comparable to Spanish Flu outbreak. To date, 9,866,710 individuals have tested positive in Brazil, as well as 239,773 lost their lives as result of COVID-19 complications, according to government data (BRASIL, 2021). According to official source, the incidence in Brazil is 4695.1/100,000 inhabitants, mortality is $114.10 / 100,000$ inhabitants and the lethality is $2.5 \%$. Although a total of $8,805,239$ "recovered" are mentioned, it cannot be excluded that part of these patients has sequelae physical and/or emotional. It will take us years to faithfully compute this data to its fullest and to understand the real dimensions of the COVID-19 pandemic.

According to V'KOVSKI et al. (2020) and KOYAMA et al. (2020), Novel mutations in SARS-CoV-2 have emerged as genetic variants uch as United Kindom variant, South African variant and Brazilian variant. Genetic variants of the SARS-CoV-2 virus can be more transmissible and can spread more quickly. There is no evidence to suggest that the new genetic variants of the SARS-CoV-2 virus produce more severe or lethal clinical forms (GÓMEZ-CARBALLA et al., 2020; KUPFERSCHMIDT K, 2021; RICE B, 2020; FARIA NR., et al., 2021; LAURING AS, HODCROFT EB, 2021; KORBER B, et al., 2020).

Contamination by the SARS-CoV-2 virus occurs by inhaling droplets of saliva or mucus released by coughing or sneezing from infected patients or by contact with contaminated surfaces and subsequent contact with nose, mouth and eyes (DHAND R, JIE L, 2020; PENDAR M e PÀSCOA JC, 2020).

The incubation period is usually obtained by the history of contact and the onset of symptoms. The determination of the incubation period can be influenced by the patients' memory bias or by the wrong choice of possible exposure dates by doctors or researchers.

Knowledge of the SARS-CoV-2 incubation period provides guidance on the ideal duration of the quarantine period, is fundamental in investigating the mechanism of viral transmission and allows a better understanding of the biology of the virus. An epidemiological application of knowledge of the incubation period is the calculation of the "Number R", an estimate of the number of infections caused by a single infected individual. Therefore, all scientific efforts to determine the incubation period for the SARS-CoV-2 virus are invaluable. Incubation period of SARS-CoV-2 virus was initially described as 10 to 14 days, but recent data mention 2 to 5 days. Some authors reports that ninety-five percent of patients experience symptoms within 12.5 days after contact (JIANG X, et al., 2020; SALZBERGER B, et al., 2020; YANG L, et al., 2020). 
Brazilian media has reported on parties, shows and pubs crowded, often without wearing masks. Along the coast, the beaches are full of bathers enjoying summer. In addition to social agglomerations, movement of people across the country is another important mechanism for viral dissemination. This population behavior associated to national continental dimensions, makes Brazil an ideal place for SARS-CoV-2 mutations (BATISTA CT, et al., 2020).

In this text, we analyze a small series of cases of COVID-19 within a familial cluster in which an ultrashort incubation period can be an important epidemiological data for suspecting a possible Brazilian variant of SARS-CoV-2.

\section{EXPERIENCE REPORT}

One of individuals in familial cluster (P16) is a nurse, with whom one of authors (Gilvano) maintains a professional relationship. This person reported the facts to author. So, the occurrence of COVID-19 in a familial cluster is described. A Form for collecting clinical data was prepared and sent over the internet to the participants. Everyone agreed to share personal medical information. Sending fulfilled form meant "acceptance" to participate in the research. In the case of minors, forms were sent by parents. Confidentiality regarding personally identifiable data has been guaranteed.

Nineteen people with some kind of kinship participated in a celebration dinner on New Year's Eve in the city of Hortolândia, State of São Paulo, Brazil. These individuals were followed up, with a focus on moment of onset of symptoms, having as reference on 12/31/2020 A heredogram representative of the distribution of individuals in the family clan was constructed to better understand interpersonal relationships (Figure 1). There was no intervention by researchers.

Figure 1 - Heredogram representative of the distribution of individuals in the familial cluster.

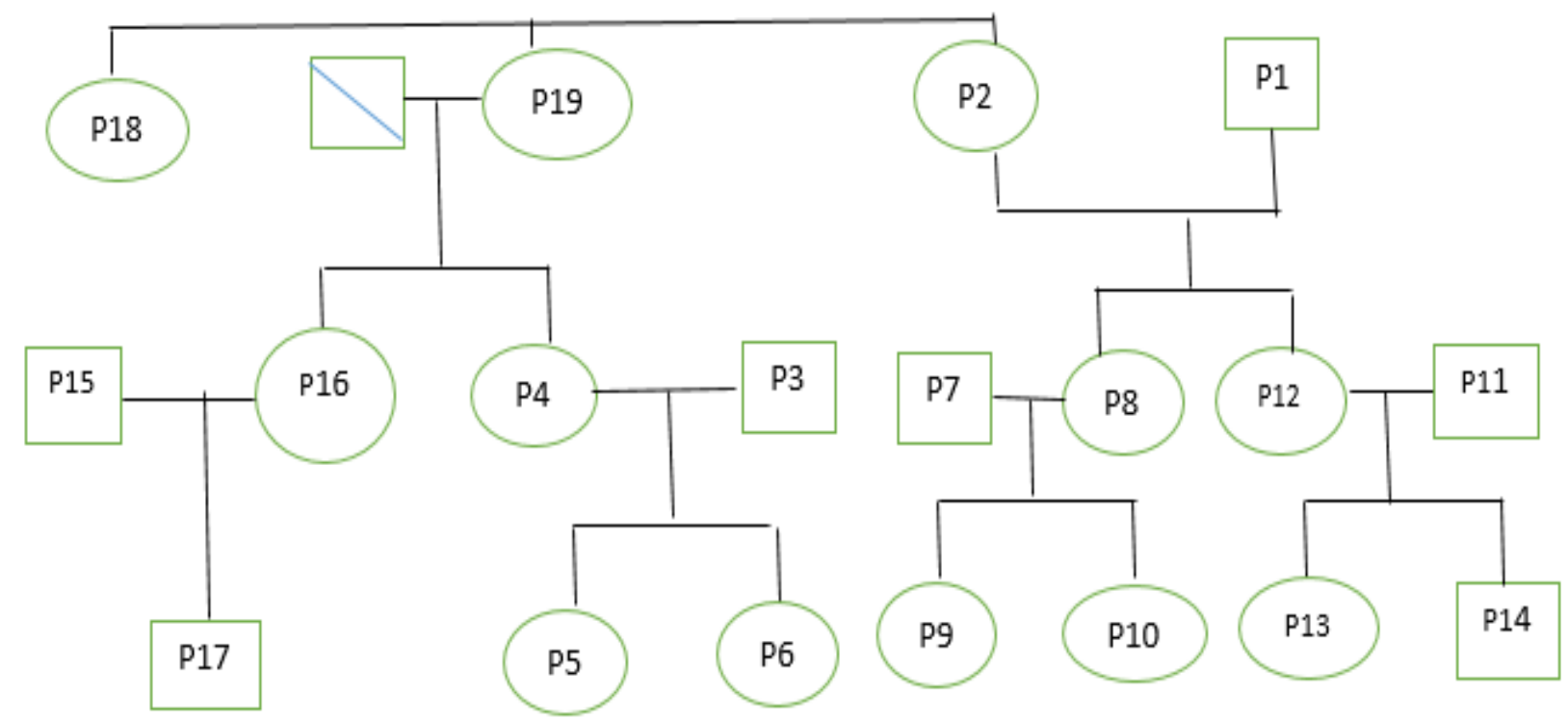

Subtitle: Circle: female; Square: male

Fonte: Oliveira GA e Oliveira GML, 2021.

The subjects were grouped according immediate families. Immediate families came from the cities of São Paulo, Hortolândia, Campinas and Bauru, in addition to one family from the city of Knoxville, Tennessee, United States (Table 1). This one stayed at the wife's parent's home in the City of Campinas for 15 (fifteen) days and returned to the USA next day after festival. Thus, for the purpose of this research and from an epidemiological point of view, this family was considered to have come from Campinas. 
Table 1 - Profile of individuals and distribution by immediate families.

\begin{tabular}{|c|c|c|c|c|c|c|}
\hline IM & Case & Gender & Age & City & Interval $^{*}$ & First Symptom $^{\text {IM }}$ \\
\hline \multirow{2}{*}{ IM 1 } & Person 1 (P1) & Male & 65 & Campinas, SP & $96 \mathrm{~h}$ & Fatigue \\
\cline { 2 - 7 } & Person 2 (P2) & Female & 65 & Campinas, SP & $36 \mathrm{~h}$ & Cough \\
\hline \multirow{4}{*}{ IM 2 } & Person 3 (P3) & Male & 49 & Hortolândia, SP & $48 \mathrm{~h}$ & Headache \\
\cline { 2 - 7 } & Person 4 (P4) & Female & 47 & Hortolândia, SP & $24 \mathrm{~h}$ & Anosmia \\
\cline { 2 - 7 } & Person 5 (P5) & Female & 18 & Hortolândia, SP & $36 \mathrm{~h}$ & Fever \\
\cline { 2 - 7 } & Person 6 (P6) & Female & 10 & Hortolândia, SP & $36 \mathrm{~h}$ & Headache \\
\hline \multirow{4}{*}{ IM 3 3} & Person 7 (P7) & Male & 40 & Knoxville, TN & $48 \mathrm{~h}$ & Cough \\
\cline { 2 - 7 } & Person 8 (P8) & Female & 40 & Knoxville, TN & $24 \mathrm{~h}$ & Couch \\
\cline { 2 - 7 } & Person 9 (P9) & Female & 14 & Knoxville, TN & $36 \mathrm{~h}$ & Cough \\
\cline { 2 - 7 } & Person 10 (P10) & Female & 10 & Knoxville, TN & $36 \mathrm{~h}$ & Headache \\
\hline \multirow{4}{*}{ IM 4 4} & Person 11 (P11) & Male & 39 & Campinas, SP & $36 \mathrm{~h}$ & Myalgia \\
\cline { 2 - 7 } & Person 12 (P12) & Female & 37 & Campinas, SP & $36 \mathrm{~h}$ & Shortness of breath \\
\cline { 2 - 7 } & Person 13 (P13) & Female & 10 & Campinas, SP & $36 \mathrm{~h}$ & Sore throat \\
\cline { 2 - 7 } & Person 14 (P14) & Male & 8 & Campinas, SP & $36 \mathrm{~h}$ & Cough \\
\hline \multirow{3}{*}{ IM 5 } & Person 15 (P15) & Male & 47 & Bauru, SP & $36 \mathrm{~h}$ & Back pain \\
\cline { 2 - 7 } & Person 16 (P16) & Female & 45 & Bauru, SP & $24 \mathrm{~h}$ & Cough \\
\cline { 2 - 7 } & Person 17 (P17) & Male & 9 & Bauru, SP & $36 \mathrm{~h}$ & Sore throat \\
\hline IM 6 & Person 18 (P18) & Female & 74 & São Paulo, SP & None & None \\
\hline IM 7 & Person 19 (P19) & Female & 76 & Bauru, SP & $36 \mathrm{~h}$ & Cough \\
\hline
\end{tabular}

Subtitle: IM: immediate families * Time (in hours) elapsed before onset of symptoms.

Fonte: Oliveira GA e Oliveira GML, 2021.

All guests reported good health, denied suspicious contacts, were feeling well and did not show any symptoms compatible with COVID-19 last days before meeting. People of familial cluster have not met recently, nor been in same places, nor with people in common in past few days. Body temperature was measured using a non-contact thermometer when subjects were admitted to the dining area. None of individuals presented measurement greater than $98.2{ }^{\circ} \mathrm{F}$. Dispensers with gel alcohol were made available and use of masks was maintained, except when feeding. Dinner tables, set up 5 feet apart, were occupied only by immediate families.

Clinical presentation, laboratory exams and pulmonary tomographic study were considered as diagnostic criteria for COVID-19. According to the conduct of the attending physician, two types of laboratory tests were used for detection of nucleic acid from SARS-CoV-2, reverse transcription polymerase chain reaction (RTPCR) and immunochromatography. In both cases, samples of the upper respiratory tract (deep oropharyngeal swabs) were collected.

Nineteen people of a familial cluster were followed up for twelve days. Twelve people were female (63.15\%). The average age was 37 years, with an individual of eight years old being the youngest and an individual of 76 years old being the oldest. Those over 60 years old represent $21.05 \%$ and those under 10 years old, $26.32 \%$. All individuals reported good health, but there was history of obesity, mild dyslipidemia, diabetes, high blood pressure, coronary artery disease, breast cancer and thyroid disorders. These clinical conditions were analyzed stable by the respective doctors.

Three individuals, one from Hortolândia (Person four), one from Campinas (Person eight) and one from Bauru (Person 16) reported first symptoms within 24 hours after meeting. In 36 hours, 15 people fell ill. Two patients (Persons three and seven) had symptoms of COVID-19 after 48 hours and the last one (Person one) was sick after 96 hours. In other words, within 96 hours, 18 of the $19(94,73 \%)$ guests manifested symptoms compatible with SARS-CoV-2 infection. The familial cluster were quarantined. The average incubation period was 37.16 hours. The incubation period was 24 hours in $11.11 \%$ of cases, 36 hours in $66.67 \%$ and 48 hours in $22.22 \%$ of individuals of the cluster. In just over five percent $(5,26 \%)$ of patients (Person one) estimated incubation period was 96 hours. The most frequent initial symptom was cough (38.8\%). (Table 1). The average incubation period for couples was $42 \mathrm{~h}$. The average incubation period for husbands was $52,8 \mathrm{~h}$. A comparison of estimated incubation period of couples are showed in the Table 2. 
Table 2 - Assessment of the incubation period of couples.

\begin{tabular}{|c|c|c|c|c|c|}
\hline Couple & Case & Interval $^{*}$ & $\begin{array}{l}\text { Average incubation } \\
\text { period for couples }\end{array}$ & $\begin{array}{l}\text { Average incubation } \\
\text { period for husbands }\end{array}$ & $\begin{array}{l}\text { Average incubation } \\
\text { period for wives }\end{array}$ \\
\hline \multirow{2}{*}{ Couple 1} & $\mathrm{P} 1$ & $96 \mathrm{~h}$ & \multirow{2}{*}{66} & \multirow{10}{*}{52,8} & \multirow{10}{*}{28,8} \\
\hline & P2 & $36 \mathrm{~h}$ & & & \\
\hline \multirow{2}{*}{ Couple 2} & P3 & $48 \mathrm{~h}$ & \multirow{2}{*}{36} & & \\
\hline & $\mathrm{P} 4$ & $24 \mathrm{~h}$ & & & \\
\hline \multirow{2}{*}{ Couple 3} & P7 & $48 \mathrm{~h}$ & \multirow{2}{*}{36} & & \\
\hline & P8 & $24 \mathrm{~h}$ & & & \\
\hline \multirow{2}{*}{ Couple 4} & P11 & $36 \mathrm{~h}$ & \multirow{2}{*}{36} & & \\
\hline & $\mathrm{P} 12$ & $36 \mathrm{~h}$ & & & \\
\hline \multirow{2}{*}{ Couple 5} & P15 & $36 \mathrm{~h}$ & \multirow{2}{*}{30} & & \\
\hline & P16 & $24 \mathrm{~h}$ & & & \\
\hline
\end{tabular}

Subtitle: * Time (in hours) elapsed before onset of symptoms

Fonte: Oliveira GA e Oliveira GML, 2021.

Of the 19 guests, 17 were tested (89.47\%). Twelve individuals tested positive for new coronavirus $(60 \%)$. In two cases, tests had not yet been carried out until end of this follow-up. Eight patients were diagnosed by RT-PCR test $(47.05 \%)$ and nine by immunochromatography $(52.94 \%)$. Of patients who underwent PCRRT test $50 \%$ tested positive and of those underwent immunochromatography $66.67 \%$ tested positive. All eighteen patients had similar clinical course, with cough, headache, sore throat, myalgia, transient shortness of breath, diarrhea, nausea, chest pain, weakness, anosmia and facial flushing. One patient (Person 12) had persistent breathing shortness, with tomographic ground-glass opacity in $20 \%$ of the lung parenchyma. At the end of 12-day follow-up, only three patients persisted with symptoms. The final course of all cases was not followed up in this research, since the incubation period was the object of study (Table 3).

Table 3 - Laboratorial Tests.

\begin{tabular}{|c|c|c|c|c|}
\hline IM & Case & Date & Type & Result of test \\
\hline \multirow{2}{*}{ IF 1 } & P1 & None & None & None \\
\cline { 2 - 5 } & P2 & $01 / 05 / 2021$ & IM & Positive \\
\hline \multirow{4}{*}{ IF 2 } & P3 & $01 / 04 / 2021$ & IM & Positive \\
\cline { 2 - 5 } & P4 & $01 / 04 / 2021$ & IM & Positive \\
\cline { 2 - 5 } & P5 & $01 / 04 / 2021$ & IM & Positive \\
\hline \multirow{4}{*}{ IF 3 } & P6 & $01 / 06 / 2021$ & IM & Positive \\
\cline { 2 - 5 } & P7 & $01 / 08 / 2021$ & RT-PCR & Positive \\
\cline { 2 - 5 } & P8 & $01 / 08 / 2021$ & RT-PCR & Positive \\
\cline { 2 - 5 } & P9 & $01 / 08 / 2021$ & RT-PCR & Negative \\
\hline \multirow{4}{*}{ IF 4 } & P10 & $01 / 08 / 2021$ & RT-PCR & Negative \\
\cline { 2 - 5 } & P11 & $01 / 07 / 2021$ & RT-PCR & Positive \\
\cline { 2 - 5 } & P12 & $01 / 07 / 2021$ & RT-PCR & Positive \\
\cline { 2 - 5 } & P13 & $01 / 07 / 2021$ & RT-PCR & Negative \\
\hline \multirow{3}{*}{ IF 5 } & P14 & $01 / 07 / 2021$ & RT-PCR & Negative \\
\cline { 2 - 5 } & P15 & $01 / 08 / 2021$ & IM & Positive \\
\cline { 2 - 5 } & P16 & $01 / 08 / 2021^{*}$ & IM & Positive \\
\hline IF 6 & P17 & None & None & None \\
\hline IF 7 & P18 & $01 / 04 / 2021^{* *}$ & IM & Negative \\
\hline \multirow{2}{*}{ Subles } & P19 & $01 / 05 / 2021$ & IM & Positive \\
\hline
\end{tabular}

Subtitle: RT-PCR: reverse transcription polymerase chain reaction IM: immunochromatography;

IF: immediate families; *First test (01/05/2021): negative. ${ }^{* *}$ Test repeated in 01/06/2021 and 01/07/2021.

Fonte: Oliveira GA e Oliveira GML, 2021.

\section{DISCUSSION}

SARS-CoV-2 virus spreads through interpersonal contact, touch of contaminated objects and inhalation of aerosols (LO GIUDICE R, 2020). Social distancing, frequent hand washing, use of $70 \%$ gel alcohol at each contact with things or people, inanimate surface disinfection with substances such as orthophenylphenol or benzalkonium chloride (KAMPF G, 2020) and use of masks (HOWARD J, 2021) are important measures to 
combat the spread of COVID - 19. Occurrence of Covid-19 within familial cluster has been described (IKITIMUR H, et al., 2021). Close contact with asymptomatic carrier during incubation period is possible mechanism of transmission (CHAN JF, et al., 2020). In present study, a family meeting probably was main viral dissemination moment. It shows that social agglomerations are high risk events for COVID-19, although adopted control measures.

Although information on the natural history of asymptomatic SARS-CoV-2 infection is scarce, it appears to be an important mechanism of viral spread (BAI Y, et al.,2020). In our study, none of the participants of dinner had previous symptoms, which leads us to think about the possibility of an asymptomatic carrier or a recently infected person (possible index case).

Anyway, this report still has its value, since the others were symptomatic into an extremely short time. Into 96 hours $94.73 \%$ of individuals was sick. All patients complained of breathing difficulty, asthenia, generalized myalgia, sore throat, anosmia, cough, severe headache, diarrhea and flushing. All cases were moderate. There were no mild cases. Uniform clinical presentation draws attention. It is noteworthy that infection by the SARS-CoV-2 virus has a higher percentage of asymptomatic or oligosymptomatic patients. An infected population generally does not have the same clinical form, as seen in these cases (SALZBERGER B, 2020).

Within 24 hours, three individuals had symptoms compatible with COVID-19, so the question of possible shortening incubation period is the most important data to be discussed. In literature, the average incubation period for SARS-CoV-2 virus is varied (TAN WYT, et al., 2020.). Some indications point an incubation period of 10 to 14 days. In our sample, the shortest average time reported was 3 days and the longest was five (5.2) days. According reports, incubation period for SARS-CoV-2 virus can take two to 14 days (BENVENUTO D, et al., 2019; GUAN W, et al., 2020; PUNG R, et al., 2020; SINGHAL T, 2020).

An incubation period lasting up to two or more weeks can make it difficult for travelers to track (WELLS CR, et al., 2020). This fact can be important in this series of cases when explaining the contamination of the group. More recently, reports have mentioned incubation period of two to five days (BAR-ON, et al., 2020). We did not find any reports that mention incubation period of 24 hours.

If this familial cluster have, in fact, a short incubation period, what should be the explanation? What should be clinical or epidemiological importance? Possible explanations for the shortening of the incubation period may be mutations in the SARS-CoV-2 virus or autochthonous aspects of the host organism. Specific patterns of contaminated family groups have been reported. Genetic aspects have been considered as determining factors to clinical presentation of COVID-19 in family groups (IKITIMUR H, et al., 2021).

Presentations with similar forms and clinical severity are described as resulting from possible genetic aspects. Occurrence of an ultrashort incubation period could be resultant of interaction between viral infection and genetic aspects of affected individuals. Contrary to this proposition, we found a very similar incubation period among members of the family group with no blood relationship. A comparison between spouses can demonstrate similarity of incubation periods. Except for couple 1, the average incubation period for couples is similar to each other and similar to the average for cluster's incubation period. Likewise, the average incubation period for husbands is very similar to the average incubation period for wives, if person 1 is not considered. Even taking person 1 into account, the average incubation period among husbands is still below that reported in the literature. This finding weakens the thesis that an ultrashort incubation period is a group-specific fact and not a biological characteristic of the virus.

Therefore, if the possible reason for an extremely short incubation period for SARS-CoV-2 virus cannot be found in aspects of the individual, it seems reasonable to assume that a viral change must have occurred. Viruses promote constant mutations and some mutations are so structured that they characterize a new viral strain. These strains are genetic variants of the virus. The variants can imply changes in viral biology, with clinical impact. (LAURING A, HODCROFT E, 2021). The importance of an eventual mutation, leading to the emergence of a Brazilian variant of the SARS-CoV-2 virus, is that, in theory, there may be clinical manifestations different from what we see today, as well as changes in response to therapies and even in response to vaccines. Therefore, it is a fact of great medical-scientific and epidemiological importance. 
Our study has notable limitations. Sample size was too small. No specific SARS-CoV-2 tests were performed before dinner. It was not possible to determine the index case. This fact makes the flow of transmission unknown and may raise questions about the incubation period. Therefore, our report should be analyzed with caution.

The occurrence of cases of COVID-19 in a familial cluster with an ultrashort incubation period may be indicative of changes in the clinical-epidemiological pattern of COVID-19. This text presents cases with incubation period of SARS-CoV-2 virus not previously described in the scientific literature. It seems to us that the incubation time of ultrashort duration and the high infectivity in the cases presented are indicative signs of new behavior of the SARS-CoV-2 virus in our country. Considering that these facts may be signs of the spread of Brazilian variants of the new coronavirus, we wanted to report as a warning to the scientific community and public health managers.

\section{REFERENCES}

1. BAI Y, et al. Presumed asymptomatic carrier transmission of COVID-19. Jama, 2020; 323 (14): 1406-1407.

2. BAR-ON, et al. Science Forum: SARS-CoV-2 (COVID-19) by the numbers. Elife, 2020; 9: e57309.

3. BATISTA CT, et al. Evolução Genômica do 2019-nCoV: Revisão Sistemática da Literatura. Revista de Saúde-RSF , 2020;7(2).

4. BENVENUTO D, et al. The 2019-new coronavirus epidemic: evidence for virus evolution. J Med Virol., 2020;92:455-9.

5. BRASIL. MINISTÉRIO DA SAÚDE. 2021. Painel Coronavirus [Internet]. Disponível em: https://covid.saude.gov.br/. Acessado em 02/15/2021

6. CHAN JF, et al. A family cluster of pneumonia associated with the 2019 novel coronavirus indicating person-to-person transmission: a study of a family cluster, Lancet, 2020; 395 (10223): 514-523

7. DHAND R, JIE L. Coughs and sneezes: their role in transmission of respiratory viral infections, including SARS-CoV2. American journal of respiratory and critical care medicine, 2020; 202(5): 651-659.

8. FARA A, et al. Cytokine storm and COVID-19: a chronicle of pro-inflammatory cytokines. Open biology, 2020; 10(9): 200160.

9. FARIA NR, et al. Genomic characterisation of an emergent SARS-CoV-2 lineage in Manaus: preliminary findings. Virological, 2021.

10. GÓMEZ-CARBALLA A, et al. Mapping genome variation of SARS-CoV-2 worldwide highlights the impact of COVID19 super-spreaders. Genome Research, 2020; 30.10: 1434-1448.

11. GUAN W, et al. Clinical characteristics of corona virus disease 2019 in China. N Engl J Med,. 2020; 1-13.

12. HOWARD J, et al. Uma revisão de evidências de máscaras faciais contra COVID-19. Proceedings of the National Academy of Sciences, $2021 ; 118,4$.

13. IKITIMUR $\mathrm{H}$, et al. Determining host factors contributing to disease severity in a familial cluster of 29 hospitalized SARS-CoV-2 patients: Could genetic factors be relevant in the clinical course of COVID-19?. Journal of medical virology, 2021; 93 (1). 357-365.

14. JIANG X, et al. Does SARS-CoV-2 has a longer incubation period than SARS and MERS? .Journal of medical virology, 2020; 92 (5): 476-478.

15. KAMPF G, et al. Persistence of coronaviruses on inanimate surfaces and their inactivation with biocidal agents. Journal of hospital infection, 2020; $n$ 104.3: 246-251.

16. KORBER B, et al. Rastreamento de alterações no pico de SARS-CoV-2: evidência de que o D614G aumenta a infectividade do vírus COVID-19. Cell, 2020; 182:4: 812-827.

17. KOYAMA T, et al.. Variant analysis of SARS-CoV-2 genomes. Bulletin of the World Health Organization, 2020; 98(7): 495.

18. KUPFERSCHMIDT K. Fast-spreading UK virus variant raises alarms. Science, 2021; 371(6524): 9-10.

19. LAI C et al. Severe acute respiratory syndrome coronavirus 2 (SARS-CoV-2) and corona virus disease-2019 (COVID19): the epidemic and the challenges. International journal of antimicrobial agents 2020; 105924.

20. LAURING AS, HODCROFT EB. Genetic Variants of SARS-CoV-2-What Do They Mean?. JAMA, 2021

21. $\mathrm{Li} \mathrm{H}$, et al. Coronavirus disease 2019 (COVID-19): current status and future perspective. International journal of antimicrobial agents, 2020; 105951.

22. LO GIUDICE R. The Severe Acute Respiratory Syndrome Coronavirus-2 (SARS CoV-2) in Dentistry. Management of Biological Risk in Dental Practice. International Journal of Environmental Research and Public Health, 2020; 17(9): 3067.

23. PENDAR M, PÁSCOA JC. Numerical modeling of the distribution of virus carrying saliva droplets during sneeze and cough. Physics of Fluids,2020; 32(8): 083305.

24. PENG $J$ et al. Diagnostic value of peripheral hematologic markers for coronavirus disease 2019 (COVID-19): a multicenter, cross-sectional study. Journal of clinical laboratory analysis 2020; 34(10): e23475.

25. PORTE $L$ et al. Evaluation of a novel antigen-based rapid detection test for the diagnosis of SARS-CoV-2 in respiratory samples. International Journal of Infectious Diseases 2020; 99: 328-333. 
26. PUNG R, et al., Investigation of three clusters of COVID-19 in Singapore: implications for surveillance and response measures. The Lancet, 2020; 395(10229): 1039-1046.

27. RIBES A, et al. Thromboembolic events and Covid-19. Advances in Biological Regulation, 2020; 100735.

28. RICE BL, et al. High variation expected in the pace and burden of SARS-CoV-2 outbreaks across sub-Saharan Africa. medRxiv, 2020.

29. SALZBERGER B, et al. Epidemiology of SARS-CoV-2. Infection, 2020: 1-7.

30. SINGHAL T. A review of coronavirus disease-2019 (COVID-19). Indian J Pediatr., 2020; 87(4): 281-286.

31. TAN WYT, et al. Does incubation period of COVID-19 vary with age? A study of epidemiologically linked cases in Singapore. Epidemiology \& Infection. 2020; 148.

32. TRAMPUZ A, WIDMER A F. Hand hygiene: a frequently missed lifesaving opportunity during patient care. Mayo clinic proceedings. Elsevier 2004; 79 (1).

33. V'KOVSKI P, et al. Coronavirus biology and replication: implications for SARS-CoV-2. Nature Reviews Microbiology, 2020: 1-16.

34. VILLAPOL S. Gastrointestinal symptoms associated with COVID-19: impact on the gut microbiome. Translational Research, 2020.

35. WELLS CR, et al., et. Impact of international travel and border control measures on the global spread of the novel 2019 coronavirus outbreak. PNAS, 2020;117(13):7504-7509.

36. YANG L, et al. Estimation of incubation period and serial interval of COVID-19: analysis of 178 cases and 131 transmission chains in Hubei province, China. Epidemiology \& Infection, 2020;148. 